\title{
Ю.В. Костомарова
}

ФИЦ Тюменский научный центр СО РАН ул. Малыгина, 86, Тюмень, 625026

E-mail: jvkostomarova@yandex.ru

\section{КАМЕННЫЕ ОРУДИЯ В ХОЗЯЙСТВЕННОЙ ДЕЯТЕЛЬНОСТИ НАСЕЛЕНИЯ ЭПОХИ ПОЗДНЕЙ БРОНЗЫ ЛЕСОСТЕПНОГО ПРИТОБОЛЬЯ}

Представлены результаты комплексного изучения каменных орудий труда, использовавшихся населением лесостепного Притоболья в бронзовом веке. Охарактеризовано сырье на основе петрографрического анализа коллекций, намечены основные пути поступления камня на рассматриваемую территорию. Реконструированы приемы камнеобработки. В качестве заготовок выступали песчаниковые и алевролитовые плитки, гальки разной толщины и размеров, чаще всего не нуждавшиеся во вторичной обработке, либо она сводилась к обивке и абразивной технике. Полученные результаты соотнесены с данными трасологического анализа. Выявлены и описаны признаки сработанности на типологически схожих инструментах. Установлено, что каменный инвентарь продолжал играть важную роль в производственной деятельности, прежде всего в металлообработке. В других производствах он применялся реже. Практически не фриксируются культурно-хронологические различия в сырье, ассортименте орудий и технологии их изготовления.

Ключевые слова: бронзовый век, лесостепное Притоболье, каменные орудия труда, сырье, технология, функциональная атрибуция.

\section{DOI: 10.20874/2071-0437-2017-39-4-028-036}

Каменные орудия труда и их фррагменты являются одной из самых многочисленных категорий находок на памятниках эпохи бронзы лесостепного Притоболья. Однако информационный потенциал данного вида источников для реконструкции хозяйственно-производственной деятельности использован не в полном объеме. Исследователи в основном приводят типологическую характеристику изделий. Практически не изучены состав сырья, его происхождение, технология обработки камня, далеко не все орудия функционально атрибутированы и не могут быть однозначно соотнесены с конкретным производством. Решение этих задач позволит дополнить данные об экономике древнего населения Тоболо-Исетского междуречья в бронзовом веке. Выявление и определение назначения каменного инструментария в комплексах бронзового века и более поздних периодов осложнено тем, что значительную его часть трудно диагностировать. Внешне орудия представляют собой невыразительные обломки породы - разных размеров плитки, валуны и гальки. К настоящему времени накоплен значительный опыт изучения функций макроорудий по материалам достаточно обширной территории, в том числе имеются отдельные исследования по памятникам Зауралья [Семенов, 1957; 1968, с. 3-14; Потемкина, 1985; Зданович, Коробкова, 1988; Валентин-перешеек..., 1987, с. 44-120; Пряхин, 1996, с. 80-94; Коробкова, 2001; Коробкова, Виноградов, 2004; Коробкова, Шапошникова, 2005; Древнее Устье..., 2013; Голубева, 2016; и др.].

Целью работы является обобщение результатов комплексного исследования каменных орудий с памятников эпохи поздней бронзы лесостепного Притоболья и определение роли каменного инвентаря в производственной деятельности древнего населения. Для этого, во-первых, был проведен петрографический анализ орудий, позволивший сделать вывод об основных видах горных пород и минералов, использовавшихся в камнеобработке; рассмотрено, каким образом сырье могло поступать на рассматриваемую территорию, где отсутствуют его выходы на дневную поверхность. Во-вторых, выявлены основные приемы обработки камня; в-третьих, с помощью трасологического анализа установлены функции большинства орудий, что позволило сделать вывод об ассортименте и значимости каменных инструментов. Кроме того, интерес представляет выявление зависимости между сырьем, технологией изготовления и назначением предмета.

Основной источниковый фонд исследования составили каменные изделия с поселений и городищ эпохи поздней бронзы, расположенных в границах Тоболо-Исетского междуречья: Ук 3 , Нижнеингальское 3, Дуванское XVII, Черемуховый Куст, Курья 1, Ботники 1в, Заводоуковское 11, 
Большой Имбиряй 10, Имбиряй 3, Ольховка, Хрипуновское 1, Щетково 2, Коловское, Красногорское. Поселения Ук 3 и Нижнеингальское 3 содержат в том числе алакульские материалы, Дуванское XVII, Черемуховый Куст, Курья 1 - федоровские. Памятники Ботники 1в, Заводоуковское 11 относятся к пахомовской культуре; селища Ольховка, Имбиряй 3 , Хрипуновское 1 к черкаскульской. Материалы поселения Большой Имбиряй 10 отражают факт сосуществования и взаимодействия указанных групп населения. На селище Щетково 2 выделяется два культурно-хронологических комплекса - федоровский и бархатовский. Последний также характеризуют древности с Коловского и Красногорского городищ. Кроме того, в работе использованы единичные орудия с поселений Криволукское 7, Ук XIV, Заводоуковское $9^{1}$. Всего изучено более 700 изделий, их фрагментов и обломков без следов использования.

Трасологический анализ и микрофотографии следов сработанности на орудиях выполнены с помощью панкратического микроскопа MC-2 Z00M с камерой Canon EOS-1100.

Для изготовления орудий отбирались гальки и плитки разных размеров и толщины - в зависимости от функционального назначения. Петрографически изучено 352 предмета ${ }^{2}$. Результаты этих исследований частично опубликованы [Матвеев и др., 2004, с. 160-161; Костомарова, Козлов, 2008, с. 406-408]. Как видно из табл. 1, самым распространенным поделочным материалом для орудий на всех поселениях были осадочные горные породы в разной степени измененные: песчаники (27,5\%), алевролиты (14,2\%) и их разновидности.

Таблица 1

\section{Результаты петрографического анализа каменных предметов (шт.) с памятников эпохи поздней бронзы лесостепного Притоболья}

\begin{tabular}{|c|c|c|c|c|c|c|c|c|c|c|c|c|}
\hline № & Горные породы и минералы & НИ 3 & ЧК & 3у 11 & Б 1B & БИ 10 & ИМБ 3 & Ольховка & щ 2 & Кол. гор. & Кр. гор. & $\begin{array}{l}\text { Всего, } \\
\text { шт./\% }\end{array}$ \\
\hline \multicolumn{13}{|c|}{ Горные породы } \\
\hline \multicolumn{13}{|c|}{ Осадочные: } \\
\hline 1 & Песчаники & 7 & 16 & 4 & 2 & 15 & 3 & 14 & 22 & 9 & 5 & $97 / 27,5$ \\
\hline 2 & Алевролиты & 1 & 7 & 5 & 5 & 9 & 4 & 5 & 4 & 5 & 6 & $51 / 14,5$ \\
\hline 3 & Аргилиты & - & 4 & 1 & - & 2 & - & 2 & 1 & - & - & $10 / 2,8$ \\
\hline 4 & Мергели & - & - & 一 & - & 一 & 一 & - & - & 2 & - & $2 / 0,6$ \\
\hline \multicolumn{13}{|c|}{ Магматические: } \\
\hline 5 & Базальты, диабазы & - & 4 & - & 1 & 4 & 2 & 1 & 4 & 3 & 2 & $21 / 6$ \\
\hline 6 & Граниты & - & 2 & - & - & 2 & 1 & 1 & 6 & 3 & 2 & $17 / 4,8$ \\
\hline 7 & Порфириты, андезиты & - & 2 & - & - & 1 & - & - & 7 & 1 & 1 & $12 / 3,4$ \\
\hline 8 & Спилиты & - & 1 & - & - & 2 & - & 1 & - & 1 & - & $5 / 1,4$ \\
\hline 9 & Туфы & - & - & - & - & - & - & 1 & 1 & 3 & - & $5 / 1,4$ \\
\hline 10 & Габбро & 一 & 1 & 一 & 一 & 1 & 一 & 一 & 1 & 1 & - & $4 / 1,1$ \\
\hline 11 & Полевошпатовая порода & 一 & - & 一 & 1 & 1 & 一 & - & 一 & 一 & 一 & $2 / 0,6$ \\
\hline 12 & Лидиты & - & - & - & - & - & - & - & 1 & - & - & $1 / 0,3$ \\
\hline 13 & Миасскиты & - & - & - & - & - & - & - & 1 & - & - & $1 / 0,3$ \\
\hline 14 & Микродиориты & 一 & 一 & 一 & 一 & 一 & 一 & 一 & 1 & 一 & 一 & $1 / 0,3$ \\
\hline \multicolumn{13}{|c|}{ Метаморфические: } \\
\hline 15 & Кварциты & 2 & 3 & - & 3 & 5 & - & 1 & 9 & 3 & 2 & $28 / 8$ \\
\hline 16 & Роговики & - & 2 & - & 3 & - & - & 1 & 10 & - & 1 & $17 / 4,8$ \\
\hline 17 & Сланцы тальковые & - & 2 & - & 2 & 3 & 2 & 1 & 3 & 2 & 1 & $16 / 4,5$ \\
\hline 18 & Сланцы кристаллические & 1 & 3 & 2 & 1 & 1 & - & 一 & 4 & 2 & - & $14 / 3,9$ \\
\hline 19 & Мраморы & - & - & - & - & - & - & 1 & - & - & - & $1 / 0,3$ \\
\hline 20 & Серпентиниты & - & - & - & - & - & - & - & 1 & - & - & $1 / 0,3$ \\
\hline \multicolumn{13}{|c|}{ Минералы } \\
\hline 21 & Халцедон & 3 & - & - & 1 & 2 & 一 & 1 & 2 & 一 & 一 & $9 / 2,6$ \\
\hline 22 & Кварц & 1 & 1 & 一 & - & 6 & 1 & 12 & 3 & 1 & 1 & $28 / 8$ \\
\hline 23 & Бурый железняк (лимонит) & - & - & - & 2 & - & - & - & 3 & 1 & - & $6 / 1,7$ \\
\hline 24 & Яшма & - & - & - & - & 1 & - & 1 & 1 & - & - & $3 / 0,9$ \\
\hline \multicolumn{2}{|c|}{ Итого } & 15 & 48 & 12 & 21 & 55 & 15 & 43 & 87 & 35 & 21 & $352 / 100$ \\
\hline
\end{tabular}

Примечание. Расшифровка названий памятников, приведенных в табл.: НИ 3 - Нижнеингальское 3 ; ЧК - Черемуховый Куст; зУ 11 - Заводоуковское 11; Б 1в - Ботники 1в; БИ $10-$ Большой Имбиряй 10; ИМБ 3 - Имбиряй 3 ; Щ 2 - Щетково 2 ; Кол. гор. Коловское городище; Кр. гор. - Красногорское городище.

1 Выражаю глубокую признательность А.В. Матвееву, Н.П. Матвеевой, В.А. Заху, В.И. Стефанову, О.Н. Корочковой, Е.Н. Волкову, О.М. Аношко, В.М. Костомарову за возможность трасологического анализа археологических материалов и использования полученных результатов при написании статьи.

2 Петрографический (визуальный) анализ коллекций проведен д-ром геол.-минерал. наук Е.А. Пономаревым, канд. геол.-минерал. наук Е.П. Козловым, за что автор приносит им благодарность. 


\section{Ю.В. Костомарова}

Песчаники полимиктовые, полевошпат-кварцевые, кварцевые с мусковитом, метаморфизованные. В особую группу выделяются образцы, содержащие как породообразующие минералы циркон, рутил, ильменит. Все типы имеют разную зернистость, иногда примесь мелкого гравия или талька. Они часто встречаются на Урале в составе как древних палеозойских, так и относительно молодых мезозойских образований. Ближайшие выходы таких пород на дневную поверхность или приповерхностное их залегание отмечаются на восточном склоне Южного и Среднего Урала, в бассейне рр. Миасса и Исети. Алевролиты также различны: углистые, с включениями талька, светло-серые кварцевые, метаморфизованные. Наличие углистого материала свидетельствует, что, вероятнее всего, они из мезозойской угленосной толщи ближайшего Челябинского буроугольного бассейна (районы гг. Коркино, Копейска) [Бетехтин, 2008, c. 580-584]. Обломки песчаника и алевролита благодаря абразивным свойствам и прочности использовались в качестве пестов, пассивных плиток, точильных камней.

Значительное количество орудий изготовлено из магматических горных пород: базальта, диабаза (6 \%), гранита (4,8 \%), порфирита $(3,4 \%)$, спилита, туфа $(1,4 \%)$ и др. Основные их месторождения находятся на Урале, в Челябинской области, бассейне рр. Миасса и Исети [Заварицкий, 1961, с. 206, 271, 283]. Метаморфические горные породы представлены кварцитами (8 \%), роговиками $(4,8 \%)$, тальковыми и кристаллическими сланцами (4,5 и 3,9 \%) и др. Кварциты кремовые или серые с кремовым и розовым оттенками, иногда почти белые, темно-серые мелкокристаллические. Из них изготовлены оселки, гладилки. Роговики известны на Среднем Урале (например, Мурзинско-Албашкинское месторождение) [Лазаренко, 1971, с. 330]. Тальковые породы происходят с уральских месторождений талька Шабровского, Сыростановского. По своим свойствам они неустойчивы к физическому воздействию: не могут транспортироваться далеко в водной среде, разрушаясь в непосредственной близости от коренных выходов на дневную поверхность. Этот фрактор может служить свидетельством того, что подобное сырье было взято непосредственно из коренных выходов его или из элювия и делювия. Применение талькового сланца зафиксировано при изготовлении литейных фрорм (поселения Ольховка, Имбиряй 3, Большой Имбиряй 10), когда важна мягкость материала при нанесении качественного негатива будущей отливки, в то же время эта порода характеризуется хорошими огнеупорными свойствами [Семенов, 1968, с. 144]. Кристаллические сланцы различны: мусковит-кварцевые, мусковит-полевошпат-кварцевые, алевролитовые. Среди минералов в коллекции представлены: халцедон (2,6 \%), кварц (8\%), лимонит (1,7\%), яшма (0,8 \%). Эти породы очень устойчивы к выветриванию, выдерживают длительный перенос несмотря на хрупкость. Такое сырье также широко распространенно на Южном и Среднем Урале.

В целом можно отметить разнообразие каменного сырья (24 породы с учетом их разновидностей) и примерно одинаковый минералогический состав коллекции на всех рассмотренных памятниках. По сравнению с периодами неолита - энеолита отмечается сырьевая переориентация на применение песчаников, алевролитов, базальтов и др. [Шаманаев, 2002]. Минералы группы кварца тоже использовались, но в значительно меньшем объеме. Из небольших (1,5-3 см) кварцевых галек изготовлены исключительно лощила, применявшиеся в кожевенном и керамическом производствах [Скочина, Костомарова, 2016]. Для хозяйственных нужд население эпохи бронзы лесостепного Притоболья использовало каменное сырье: небольшие обломки плиток и галечник, которые можно обнаружить по берегам близлежащих рек, куда они попадали естественным путем, в результате коллювиально-аллювиальной деятельности. Однако реки на территории Притоболья типично равнинные, со спокойным течением, небольшими скоростями и сильной извилистостью русла, что затрудняло перенос крупного обломочного материала. Следовательно, наряду с местным использовалось привозное сырье, западный путь поступления которого наиболее вероятен. К сожалению, визуальный петрографический анализ не позволяет более точно определить месторождения камня.

На втором этапе исследования был проведен микроанализ каменных изделий и их фрагментов. Из более чем 700 предметов почти половина представляли собой обломки без какихлибо следов или небольшие фррагменты с пришлифованными участками, атрибутировать которые проблематично. Соотнести с конкретным производством удалось около 300 предметов. Для изучения технологии обработки камня наиболее подходящими являлись целые предметы или крупные обломки (около 150 шт.). Для орудий отбирались гальки овальной, прямоугольной формы размерами от 1,5 до 20 см; плитки и обломки породы подпрямоугольных очертаний разных размеров, толщиной от 0,5 до 5-6 см, требовавшие минимальной доработки или не нуж- 
давшиеся в ней. Таковы заготовки, предназначенные для абразивов, лощил по коже и керамике, пестов для растирания и измельчения, часть пассивных плит, молотков, отбойников: всего около 100 предметов. Первичная обработка сводилась к раскалыванию. Оформление рабочей площадки, реже - обушковой или боковой частей орудий производилось обивкой или пикетажем (рис. 1, 1, 5, 10). Эта техника сопровождалась последующей абразивной обработкой поверхности, направленной на выравнивание, устранение выбоин, сколов и шероховатостей (рис. 1, 2).

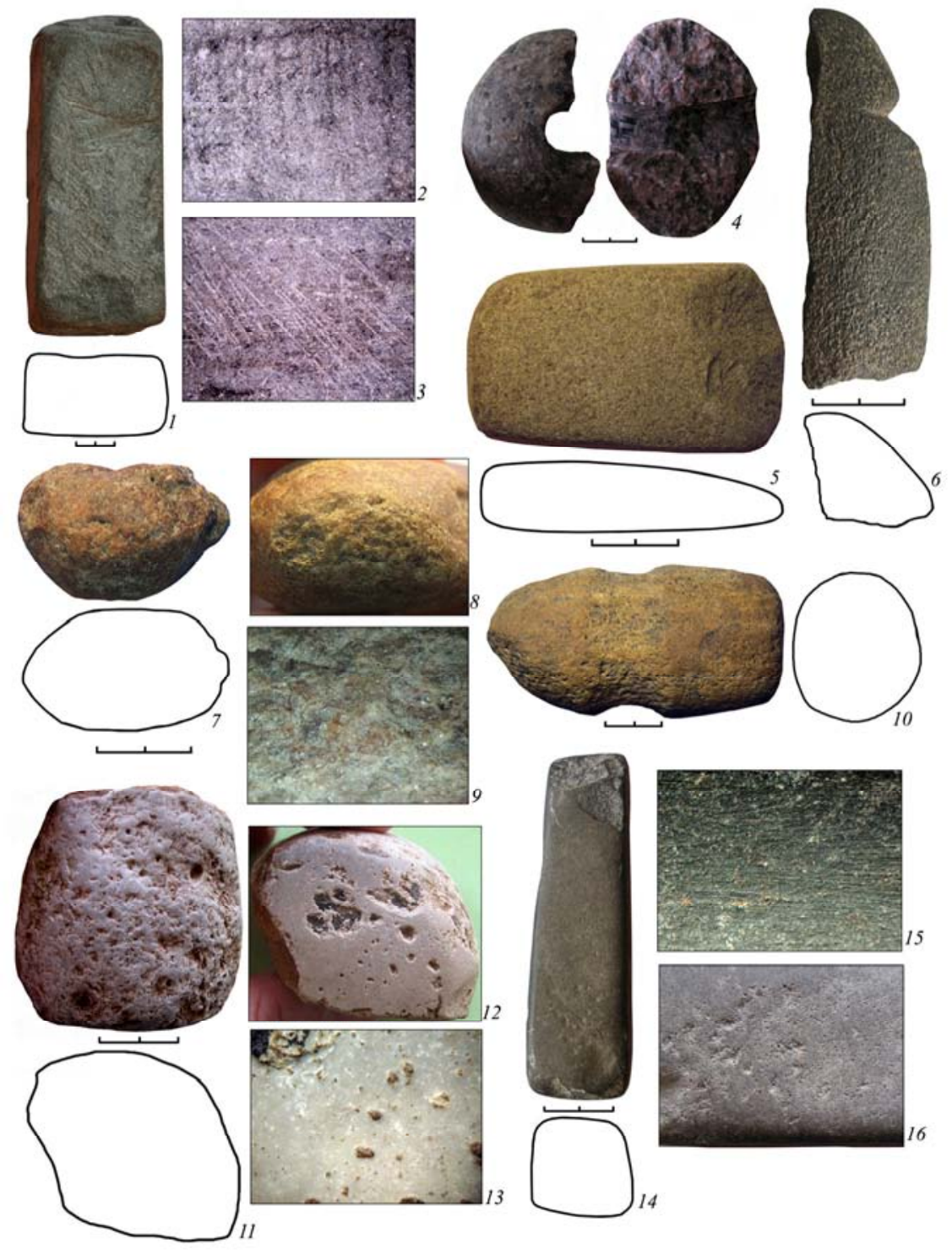

Рис. 1. Ассортимент каменных орудий труда с памятников эпохи поздней бронзы лесостепного Притоболья и следы сработанности на них:

1 - заготовка; 2 - следы обивки на заготовке, увеличение 10х; 3 - следы абразивной обработки, увеличение 10х; 4- булава; 5 - топор; 6 - оселок; 7 - пест для растирания-измельчения; 8 - рабочая площадка песта; 9 - следы сработанности на рабочей площадке песта, увеличение $7,5 \times ; 10$ - молоток для ковки; 11 - гладилка; 12 - рабочая площадка гладилки; 13 - следы сработанности на рабочей площадке гладилки, увеличение $10 x ; 14$ - полифункциональное орудие (гладилка, подставка для ковки); 15 - следы сработанности на рабочей поверхности, увеличение 10х; 16 - следы сработанности от ковки металла, увеличение 5×): 1-3 - Хрипуновское 1; 4 - Щетково 2; 5- Черемуховый Куст; 6, 14, 16 - Большой Имбиряй 10; 7-9 - Ботники 1в; 10-УК XIV; 11-13 - Заводоуковское 11.

Сочетание обивки/пикетажа и абразивной техники отмечено в 52 случаях. Оно использовалось, например, при оформлении рабочей площадки на некоторых гладилках, использовавшихся в металлопроизводстве (рис. 1, 12). Иногда абразивную обработку трудно отличить от следов сработанности, либо она перекрыта ими. На некоторых орудиях зафиксирован только один 


\section{Ю.В. Костомарова}

из обозначенных приемов (обивка - 6 случаев, абразивная обработка - 9). Единичны техники пиления и сверления камня. Пиление отмечено на трех предметах (Большой Имбиряй 10, Ольховка) (рис. 1, 6). Возможно, оно применялось чаще, но последующая вторичная обработка поверхности нивелировала следы. Сверление применялось при оформлении отверстий на оселке и булавах, обнаруженных на поселениях Щетково 2, Ук 3 (рис. 1, 4). Эти изделия характеризуются сочетанием обивки, сверления, абразивной обработки, полировки. Булава из алакульского культурно-хронологического комплекса селища Ук 3 размером $7,2 \times 4,5$ см изготовлена из породы, близкой к трахиту или сиенитовому порфиру, имеет овально-уплощенную фрорму; отверстие сделано способом встречного сверления, асимметричное, сужается к центру [Корякова и др., 1991, с. 29, рис. 16, 1]. Выступы оформлены с помощью пикетажа и затем пришлифованы. Аналогичное изделие, размером 5,8×4 см, из серпентинита, с поселения Щетково 2 также имеет биконическую фрорму и сквозное отверстие диаметром около 2 см. Вся его поверхность тщательно заполирована. Для еще одной булавы с этого памятника сырьем послужил обломок гранодиорита. Диаметр предмета 7,8 см, высота 5,5 см. Имеется сквозное отверстие, поверхность зашлифована (рис. 1, 4). По мнению исследователей, эти изделия могли являться символом власти, т.е. выполняли не утилитарные, а сакральные функции. То же можно сказать об оселках [Грязнов, 1961, с. 139-144; Хлопин, 1983, с. 24].

Можно сделать вывод о незначительном количестве приемов обработки камня. С этим процессом связаны немногочисленные орудия: отбойники (6 шт.), абразивы (8 шт.), не исключено применение бронзовых долот (рис. 1, 2). В целом же население бронзового века использовало куски камня, максимально приближенные по размерам и форме к будущему изделию. Большая часть заготовок не подвергалась какой-либо доработке. Исключение составляют предметы непроизводственной сферы. Престижный статус этих изделий обусловил, во-первых, избирательность в сырье, во-вторых, более сложную процедуру обработки. Сравнение способов работы с камнем у разнокультурных групп эпохи бронзы показало, что помимо технологии изготовления макроорудий, основанной на применении раскалывания, обивки, пикетажа, алакульское население Притоболья применяло технику двухсторонней отжимной ретуши. Таким способом изготовлены наконечники стрел - 17 шт. Сырьем для них служили отщепы из халцедона, яшмоидов. Подавляющее их большинство связано с погребальными комплексами Чистолебяжского и Хрипуновского могильников. Подобная традиция широко представлена в материалах синташтинских, петровских и потаповских поселенческих и погребальных комплексов [Васильев и др., 1994, с. 62; Генинг и др., 1992, рис. 37, 3; 51, 1-6; 161, 1-3; 171, 1, 2; Зданович, 1988, рис. 30, 16-21; 31, 1-5]. На памятниках федоровской, черкаскульской, пахомовской и бархатовской культур подобный прием эпизодичен. В целом наблюдается преемственность в технологии отделки камня и ассортименте макроорудий у рассмотренных групп населения.

В типологическом отношении каменный инвентарь с поселений эпохи поздней бронзы Притоболья включает песты, пассивные плитки, отбойники, точильные бруски, лощила, скребки, литейные фрормы, булавы, оселки, топоры, долота и др (рис. 1). У части изделий типологические характеристики соответствуют функциональным. Так, можно с уверенностью связать с обработкой дерева единичный топор и долота, с отливкой бронз и их доработкой - литейные формы, оселки; с обработкой шкур - скребки. Экспериментальным путем установлено, что небольшие кварцитовые гальки использовались при лощении шкур, кож и при обработке поверхности керамических сосудов [Скочина, Костомарова, 2016].

Наибольшие трудности вызывает фрункциональная атрибуция пестов (48 шт.), точильных камней (38 шт.), пассивных плит (61 шт.). С помощью микроскопического изучения удалось выявить группы орудий с одинаковыми блоками следов. Песты представляют собой крупные гальки вытянутых пропорций, редко приземистых, с округлым или овальным поперечным сечением. Они использовались без дополнительной обработки, либо рабочий участок, находившийся на торцевых гранях, уплощен обивкой и пришлифован. По характеру следов износа выделено несколько групп орудий. К первой (13 шт.) отнесены гальки естественных фрорм, длиной до 15-18 см; их торцевая часть в большинстве случаев предварительно не обработана, признаки использования хорошо различимы и включают мелкие выбоинки, иногда бороздки (рис. 1, 7-9). Поверхность часто выпуклая в сечении, переход к боковым участкам нечеткий. Вторая группа (12 шт.) отличается от предыдущей более выраженными следами износа - выбоинки и сколы крупнее, поверхность неровная. Третья группа (9 шт.) - крупные (8-10 см) и небольшие (4-6 см) продолговатые изделия; поперечное сечение их могло быть как округлым, так и подпрямо- 


\section{Каменные орудия в хозяйственной деятельности населения эпохи поздней бронзы...}

угольным, у некоторых (3 шт.) нанесен желобок у одного из окончаний или посередине. Желобок сформирован обивкой и, возможно, разделяет рабочую часть и рукоять орудия (рис. 1, 10). Рабочей частью являлся торец предмета: на нем отмечаются забитость, небольшие сколы и выбоинки явно от ударных действий. Четвертая группа (14 шт.) изделий включает чаще приземистые крупные гальки (до 10 см в длину) с предварительно уплощенными пришлифованными торцами, на которых фриксируются тусклая заполировка, металлический блеск, тонкие параллельные друг другу линейные следы в виде царапин, иногда мелкие выбоинки (рис. 1, 11-13). Переход от рабочей зоны к боковым поверхностям чаще приострен. Помимо рассмотренных встречены изделия, на которых удалось зафиксировать сочетание нескольких групп признаков (рис. 1, 14-16).

На основании опубликованных данных микроанализа как самих археологических, так экспериментальных образцов песты первой группы можно связать с переработкой относительно мягких материалов, возможно продуктов собирательства; вторая группа предназначалась для измельчения или растирания более твердых материалов - шамота, дресвы. Признаки износа, характерные для пестообразных орудий третьей и четвертой групп, зафиксированы рядом исследователей на инструментах, задействованных в металлообработке: молотках для ковки и гладилках для разгонки, вытяжки предметов, получении листового металла и др. [Потемкина, 1985, рис. 44, 8, 9; Зданович, Коробкова, 1988; Пряхин, 1996, с. 80-93; Коробкова, 2001; Коробкова, Шапошникова, 2005, с. 121, 172; Древнее Устье..., 2013, с. 307-309; Кунгурова, Варфоломеев, 2013].

Точильные камни, представленные плитками или брусками шириной от 3-5 см до 13,5 см и толщиной до 1,5 см, также характеризуются разными следами сработанности. Для их изготовления подбиралось сырье с хорошими абразивными свойствами - песчаник, мета-, алевропесчаник. По характеру следов износа, особенностям их расположения и интенсивности они разделены на три группы. К первой (24 шт.), самой многочисленной, отнесены орудия с пришлифованной одной стороной или торцевыми участками. Фиксируются линейные следы в виде коротких параллельных друг другу рисок, иногда металлический блеск. Данные образцы, судя по опубликованным данным, использовались в операциях, связанных с металлообработкой: с их помощью происходила доработка только что отлитых бронзовых предметов, избавление их от швов, заусениц, неровностей; некоторыми производилась ежедневная подправка и заточка лезвий бронзовых ножей, серпов и других предметов. На рабочей поверхности точильных камней второй группы (6 шт.) наблюдаются углубления в виде конусообразных небольших желобков, заполировка отсутствует. Аналогичные признаки фриксируются на абразивах, предназначенных для обработки поверхности костяных изделий. Еще на восьми предметах рабочей является большая плоская сторона, степень сработанности выражена значительно ярче и четче, поверхность выровнена иногда до блеска, линейные следы - тонкие удлиненные риски. Похожие следы отмечаются на абразивах по камню.

Пассивные плитки разнообразны по размерам и фрорме, иногда им придавалась округлая форма. Значительная часть этих предметов представлена фррагментами, что затрудняет их функциональную атрибуцию. Первая группа изделий (17 шт.) характеризуется следующим признаками износа: поверхность выровнена, иногда вогнута из-за продолжительного использования, на ней фриксируются выбоинки, лунки, бороздки, а выступающие участки пришлифованы. Скорее всего, они служили площадками для растирания, измельчения, дробления различных по твердости материалов, от которой и зависела интенсивность износа. Несколько плит (14 шт.) характеризуются ровной рабочей площадкой, на которой присутствуют лунки, образующие несколько скоплений или расположенные хаотично. Подобные признаки присущи подставкам для ковки металлических изделий. Таким образом, удалось дифференцировать внешне схожие орудия по следам сработанности и определить их фрункциональную принадлежность.

Каменный инструментарий находил применение во всех основных видах хозяйственной деятельности: в обработке кожи, кости, дерева, камня, продуктов собирательства, изготовлении глиняной посуды. Но наиболее важную роль он играл в металлообработке, именно с этой отраслью связано большинство орудий и их функционально-типологическое разнообразие.

В целом комплексный анализ каменных орудий труда с памятников эпохи поздней бронзы показал однородность материалов: практически не фриксируются культурно-хронологические различия в сырье, ассортименте орудий и технологии их изготовления. В этом контексте следует отметить, во-первых, использование алакульским населением ретушированных наконечников стрел, но в основном в погребальной практике; во-вторых, активное применение черка- 


\section{Ю.В. Костомарова}

скульскими группами небольших галек-лощил. Сырьевая база камнеобработки представлена как местными источниками: небольшими обломками и валунами аморфной формы, которые могли перемещаться по водным артериям либо находиться в коллювиально-делювиальных отложениях, выходящих на поверхность Тобола и Исети, так и привозным сырьем (крупные плитки, окатанные валуны), поступавшим с месторождений Среднего и Южного Урала в результате торгово-обменных операций. Для хозяйственно-производственных нужд использовались гальки и плитки песчаника, алевролита, кварцита, сланцы. При изготовлении орудия учитывались фризические свойства материала, прежде всего прочность и абразивность. В ряде случаев установлена закономерная связь между сырьем и функцией предмета. Технология обработки камня не отличалась разнообразием, первичная обработка сводилась к раскалыванию, вторичная - к обивке и абразивной обработке (грубой и более аккуратной пришлифовке). При этом происходило оформление только рабочих площадок, реже - боковых сторон или периметра. Только при изготовлении престижных вещей применялась более многоступенчатая схема, включавшая еще станковое сверление. Значительная часть орудий представляют собой необработанные обломки пород. Минимизацию временных затрат на производство инструментов можно рассматривать как прогрессивную черту хозяйственной деятельности андроновского и андроноидного населения Притоболья. В функциональном отношении каменный инструментарий был задействован прежде всего в металлообработке на стадиях отливки, дальнейшей доводки и подправки изделий. Кроме того, многочисленные песты и терочники применялись при дроблении-растирании различных материалов. В остальных отраслях орудия из камня использовались эпизодически и играли скорее второстепенную роль. Так, в кожевенном производстве они заменялись на костяной и керамический инструментарий; повсеместно были в ходу металлические орудия. Подобная тенденция использования макроорудий и их отраслевая специализация найдет продолжение в более поздние эпохи [Голубева, 2016].

\section{БИБЛИОГРАФИЧЕСКИЙ СПИСОК}

Бетехтин А.Г. Курс минералогии. М.: Наука, 2008. 736 с.

Валентин-перешеек - поселок древних рудокопов. М.: Наука, 1987. 248 с.

Васильев И.Б., Кузнецов П.Ф., Семенова А.П. Потаповский курганный могильник индоиранских племен на Волге. Самара: Изд-во СамГУ, 1994. 208 с.

Генинг В.Ф., Зданович Г.Б., Генинг В.В. Синташта. Археологические памятники арийских племен Урало-Казахстанских степей. Челябинск: Южно-Урал. кн. изд-во, 1992. Ч. 1. 408 с.

Голубева Е.В. Теория и практика экспериментально-трасологических исследований неметаллического инструментария раннего железного века - средневековья (на материалах южно-таежной зоны Средней Сибири). Красноярск: Сиб. федер. ун-т, 2016. 144 с.

Грязнов М.П. Так называемые оселки скифо-сарматского времени // Исследования по археологии СССР. Л., 1961. С. 139-144.

Древнее Устье: Укрепленное поселение бронзового века в Южном Зауралье / Отв. ред. Н.Б. Виноградов. Челябинск: Абрис, 2013. Гл. 10. С. 285-330.

Заварицкий А.Н. Изверженные породы. М.: Наука, 1961. 480 с.

Зданович Г.Б. Бронзовый век Урало-Казахстанских степей. Свердловск: УрГУ, 1988. 184 с.

Зданович Г.Б., Коробкова Г.Ф. Новые данные о хозяйственной деятельности населения эпохи бронзы (по результатам трасологического изучения орудий труда с пос. Петровка II) // Проблемы археологии Урало-Казахстанских степей. Челябинск: Изд-во ЧелГУ, 1988. С. 60-79.

Коробкова Г.Ф. Функциональная типология орудий труда и других неметаллических изделий на Алтын-депе: Материалы Южно-Туркменистанской археологической комплексной экспедиции // Особенности производства поселения Алтын-депе в эпоху палеометалла. СПб., 2001. Вып. 5. С. 146-209.

Коробкова Г.Ф., Виноградов Н.Б. Каменные и костяные орудия из поселения Кулевчи III // Вестник ЧГПУ. Сер. 1, Историч. науки. 2004. Вып. 2. С. 57-87.

Коробкова Г.Ф., Шапошникова О.Г. Поселение Михайловка - эталонный памятник древнеямной культуры: (Экология, жилища, орудия труда, системы жизнеобеспечения, производственная структура). СПб.: Европ. дом, 2005. 316 с.

Корякова Л.Н., Стефранов В.И., Стефранова Н.К. Проблемы методики исследований древних памятников и культурно-хронологическая стратиграфия поселения Ук 3. Свердловск: ИИА УрО РАН, 1991. 72 с.

Костомарова Ю.В., Козлов Е.П. К вопросу о сырьевой базе каменных орудий населения позднего бронзового века Тоболо-Исетского междуречья // Труды II (XVIII) Всерос. археол. съезда в Суздале. М.: ИА $\mathrm{PAH}, 2008$. T. 1. C. 406-408.

Кунгурова Н.Ю., Варфоломеев В.В. Орудия и изделия из камня поселения Кент // Бегазы-дандыбаевская культура степной Евразии. Астана: Бегазы-Тасмола, 2013. С. 198-217. 


\section{Каменные орудия в хозяйственной деятельности населения эпохи поздней бронзы...}

Лазаренко Е.К. Курс минералогии. М.: Высш. шк., 1971. 608 с.

Матвеев А.В. Пономарев Е.А., Кияева Л.С. О минералогическом составе коллекции каменных предметов с поселения Щетково 2 // Словцовские чтения - 2004. Тюмень, 2004. Ч. 1. С. 160-161.

Потемкина Т.М. Бронзовый век лесостепного Притоболья. М.: Наука, 1985. 376 с.

Пряхин А.Д. Мосоловское поселение металлургов-литейщиков эпохи поздней бронзы. Воронеж: Издво ВГУ, 1996. Кн. 2. 176 с.

Семенов С.А. Первобытная техника // МИА. 1957. № 54. 240 с.

Семенов С.А. Развитие техники в каменном веке. Л.: Наука, 1968. 362 с.

Скочина С.Н., Костомарова Ю.В. Функциональное назначение орудий труда из галек с поселений эпохи поздней бронзы лесостепного Притоболья (экспериментально-трасологический анализ) // Археология, антропология и этнография Евразии. 2016. Т. 44. № 1. С. 72-81.

Хлопин И.Н. Юго-Западная Туркмения в эпоху поздней бронзы. Л.: Наука, 1983. 130 с.

Шаманаев А.В. Каменные индустрии мезолита - раннего бронзового века Нижнего Притоболья: Авторефр. дис. ... канд. ист. наук. СПб., 2002. 24 с.

Yu.V. Kostomarova

Tyumen Scientific Centre of Siberian Branch RAS Malygina st., 86, Tyumen, 625026, Russian Federation E-mail: jvkostomarova@yandex.ru

\section{STONE TOOLS IN THE ECONOMIC ACTIVITY OF THE POPULATION \\ OF THE LATE BRONZE AGE IN THE FOREST-STEPPE ZONE OF THE TOBOL RIVER BASIN}

The article presents the results of a complex analysis of stone tools from the sites of the Late Bronze Age in the forest-steppe zone of the Tobol river basin. The new data were obtained due to using petrographic, typological, traceological methods. They characterized household productive activities of the ancient population. It was found out that raw materials for stone working are represented, first of all, by the local sources such as small rocks and boulders that could be moved by waterways or are located in colluvial-deluvial sediments, reaching the surface of the Tobol river and the Iset river; secondly, imported raw materials originating from the fields of the Middle and Southern Urals due to the trade-exchange relations. Pebbles and tiles of sandstone, siltstone, quartzite, shale were used for household and industrial needs. Primary processing of the stone was reduced to splitting, and secondary, to lining, abrasive technology, polishing. It was the only design of working platforms, at least of the sides or of the perimeter. A multi-stage scheme was used only for making prestigious things, including still and heavy drilling. A significant portion of the tools is represented by raw debris. Minimizing the time spent on production of tools can be regarded as a progressive feature in the economic activity of the population of the Bronze Age in the Tobol river basin. The analysis of signs of use of the tools, their classification allowed us to determine the function of a significant series of products. Stone tools were involved primarily in metal processing - at the stage of casting, forging and finishing the products. Numerous pestles and passive plates were used for crushing and grinding of various materials. In other spheres, the stone tools were used sporadically and played a rather secondary role. As in the leather production they were replaced with bone and ceramic tools; metal tools were widely used. In general, a comprehensive analysis of stone tools from the monuments of the Late Bronze Age showed uniformity of materials: virtually no recorded cultural and chronological differences in the range of tools and technologies of their production were found, which shows stability and continuity of the main industries.

Key words: the Bronze Age, forest-steppe zone of the Tobol river basin, stone tools, raw materials, technology, functional attribution.

DOI: $10.20874 / 2071-0437-2017-39-4-028-036$

\section{REFERENCES}

Betekhtin A.G., 2008. Kurs mineralogii [The course of Mineralogy], Moscow: Nauka, 736 p.

Dikov N.N., 1987, (ed.). Valentin-peresheek - poselok drevnikh rudokopov [Valentin-isthmus — a settlement of ancient miners], Moscow: Nauka, $248 \mathrm{p}$.

Gening V.F., Zdanovich G.B., Gening V.V., 1992. Sintashta: Arkheologicheskie pamiatniki ariiskikh plemen Uralo-Kazakhstanskikh stepei [Sintashta: Archaeological monuments of Aryan tribes of the Ural-Kazakhstan steppes], part 1, Cheliabinsk: luzhno-ural'skoe knizhnoe izdatel'stvo, 408 p.

Golubeva E.V., 2016. Teoriia i praktika eksperimental'no-trasologicheskikh issledovanii nemetallicheskogo instrumentariia rannego zheleznogo veka - srednevekov'ia (na materialakh iuzhno-taezhnoi zony Srednei Sibiri) [Theory and practice of experimental traceological research of non-instrumentation of the Early Iron Age - Middle Ages (on materials of the southern taiga zone of Middle Siberia)], Krasnoiarsk: Sibirskii federal'nyi universitet, $144 \mathrm{p}$.

Griaznov M.P., 1961. Tak nazyvaemye oselki skifo-sarmatskogo vremeni [The so-called whetstones of the Scythian-Sarmatian period]. Issledovaniia po arkheologii SSSR, Leningrad: Nauka, pp. 139-144. 


\section{Ю.В. Костомарова}

Khlopin I.N., 1983. Iugo-Zapadnaia Turkmeniia $v$ epokhu pozdnei bronzy [South-Western Turkmenistan in the Late Bronze Age], Leningrad: Nauka,130 p.

Korobkova G.F., 2001. Funktsional'naia tipologiia orudii truda i drugikh nemetallicheskikh izdelii na Altyn-depe: Materialy luzhno-Turkmenistanskoi arkheologicheskoi kompleksnoi ekspeditsii [Functional typology of tools and other nonmetallic products at Altyn-Depe: The materials of the South-Turkmenistan archeological complex expedition]. Osobennosti proizvodstva poseleniia Altyn-depe v epokhu paleometalla, 5, St. Petersburg, pp. 146-209.

Korobkova G.F., Shaposhnikova O.G., 2005. Poselenie Mikhailovka - etalonnyi pamiatnik drevneiamnoi kul'tury: (Ekologiia, zhilishcha, orudiia truda, sistemy zhizneobespecheniia, proizvodstvennaia struktura) [Settlement Mikhailovka - the reference monument of the old pit culture: (Ecology, dwellings, tools, life support systems, production structure)], St. Petersburg: Evropeiskii dom, 316 p.

Korobkova G.F., Vinogradov N.B., 2004. Kamennye i kostianye orudiia iz poseleniia Kulevchi III [Stone and bone tools from the settlement Kulevi III]. Vestnik Cheliabinskogo gosudarstvennogo pedagogicheskogo universiteta, ser. 1, Istoricheskie nauki, 2, pp. 57-87.

Koriakova L.N., Stefanov V.I., Stefanova N.K., 1991. Problemy metodiki issledovanii drevnikh pamiatnikov $i$ kul'turno-khronologicheskaia stratigrafiia poseleniia Uk 3 [Problems of methodology of researches of ancient monuments and culture-chronological stratigraphy of the settlement Uk 3], Sverdlovsk, $72 \mathrm{p}$.

Kostomarova lu.V., Kozlov E.P., 2008. K voprosu o syr'evoi baze kamennykh orudii naseleniia pozdnego bronzovogo veka Tobolo-Isetskogo mezhdurech'ia [To the question of the source of raw materials of stone tools of the population of the Late Bronze Age, Tobol-Iset interfluve]. Trudy II (XVIII) Vserossiiskogo arkheologicheskogo s"ezda v Suzdale, vol. 1, pp. 406-408.

Kungurova N.lu., Varfolomeev V.V., 2013. Orudiia i izdeliia iz kamnia poseleniia Kent [The instruments and articles of stone or settlement of Kent [Begazy-dandybay culture of the Eurasian steppes]. Begazydandybaevskaia kul'tura stepnoi Evrazii, Astana: Begazy-Tasmola, pp. 198-217.

Lazarenko E.K., 1971. Kurs mineralogii [The course of Mineralogy], Moscow: Vysshaia shkola, $608 \mathrm{p}$.

Matveev A.V. Ponomarev E.A., Kiiaeva L.S., 2004. O mineralogicheskom sostave kollektsii kamennykh predmetov s poseleniia Shchetkovo 2 [The mineralogical composition of the collection of stone objects from the settlement Setkovo 2]. Slovtsovskie chteniia - 2004, vol. 1, Tiumen', pp. 160-161.

Potemkina T.M., 1985. Bronzovyi vek lesostepnogo Pritobol'ia [The Bronze Age of the forest-steppe Tobol region], Moscow: Nauka, $376 \mathrm{p}$.

Priakhin A.D., 1996. Mosolovskoe poselenie metallurgov-liteishchikov epokhi pozdnei bronzy [Mosolovskoe settlement of metallurgists-founders of the Late Bronze Age], book 2, Voronezh: Izd-vo VGU, 196 p.

Semenov S.A., 1957. Pervobytnaia tekhnika [Primitive technique]. MIA, no. 54, 240 p.

Semenov S.A., 1968. Razvitie tekhniki v kamennom veke [The development of technology in the Stone Age], Leningrad: Nauka, $362 \mathrm{p}$.

Shamanaev A.V., 2002. Kamennye industrii mezolita - rannego bronzovogo veka Nizhnego Pritobol'ia [The stone industry of the Mesolithic - Early Bronze Age of the Lower Tobol region]. Avtoref. dis. ... kand. ist. nauk. St. Petersburg, $24 \mathrm{p}$.

Skochina S.N., Kostomarova lu.V., 2016. Funktsional'noe naznachenie orudii truda iz galek s poselenii epokhi pozdnei bronzy lesostepnogo Pritobol'ia: (Eksperimental'no-trasologicheskii analiz) [The functionality of the tools from pebbles with settlements of the Late Bronze Age forest-steppe Tobol region: (Experimentaltraceological analysis)]. Arkheologiia, antropologiia i etnografiia Evrazii, vol. 44. no 1, pp. 72-81.

Vasil'ev I.B., Kuznetsov P.F., Semenova A.P., 1994. Potapovskii kurgannyi mogil'nik indoiranskikh plemen na Volge [Potapovskaya burial mound of the Indo-Iranian tribes on the Volga], Samara: Izd-vo SamGU, 208 p.

Vinogradov N.B., 2013, (ed.). Drevnee Ust'e: Ukreplennoe poselenie bronzovogo veka v luzhnom Zaural'e [The ancient Ustye: The fortifired settlement of the Bronze Age in the South Trans-Urals], Cheliabinsk: Abris, pp. 285-330.

Zavaritskii A.N., 1961. Izverzhennye porody [lgneous rocks], Moscow: Nauka, 480 p.

Zdanovich G.B., 1988. Bronzovyi vek Uralo-Kazakhstanskikh stepei [The Bronze Age of the Ural-Kazakhstan steppes], Sverdlovsk, $184 \mathrm{p}$.

Zdanovich G.B., Korobkova G.F., 1988. Novye dannye o khoziaistvennoi deiatel'nosti naseleniia epokhi bronzy (po rezul'tatam trasologicheskogo izucheniia orudii truda s pos. Petrovka II) [New data on the economic activity of the population of the Bronze Age (according to the results of traceological study tools from the settlement of Petrovka II)]. Problemy arkheologii Uralo-Kazakhstanskikh stepei, Cheliabinsk, pp. 60-79. 